\title{
The Fine Structure of Testicular Interstitial Cells in the Mouse Administered with Vitamin $\mathrm{E}$
}

\author{
By \\ Ichiro Ichihara \\ Department of Anatomy, Nagoya University \\ School of Medicine, Nagoya, Japan \\ (Director: Prof. Dr. Kazumaro Y a ma da)
}

\section{Introduction}

Since the reproductive disturbances of rats associated with vitamin E-deficiency were first reported by Evans \& Bishop ('22), subsequently histological changes of testes induced by vitamin Edeficient diet in rats were described by many authors. In those reports, some authors noted that testicular degeneration induced by vitamin E-deficiency was found only in seminiferous tubules and not recognized in interstitial cells (Van W a g e n e n, '25; M a s o n, '26; Evans \& Burr, '27; Kudrjaschov, '30, '31; Juhasz$\mathrm{S}$ ch a f $\mathrm{f}$ er, '31, '32; N els o n, '33; Griesbach, et al. '57), while on the other hand several authors observed histological changes in interstitial cells of rats in such condition ( $\mathrm{Marchesi}$, '35; $\mathrm{R}$ in gs te d, '36).

Furthermore, recently Fujino \& Yoshioka ('62) described that vitamin $\mathrm{E}$ administration activates the function of interstitial cells in mature mice. As described above, studies concerning the relationship between vitamin $\mathrm{E}$ and histological changes of interstitial cells of testes are not definite yet. In this study mature male mice were administered with vitamin $E$ and the interstitial cells of their testes were investigated with electron microscope with respect to their ultrastructural changes. On the basis of this study, the author presents in this paper the close relationship between vitamin $E$ and the function of interstitial cells of testes in mature male mice.

\section{Materials and Methods}

A total of 20 mature male mice of dd strain were used in this study. They were divided into two groups. The first group was 10 
normal intact mice. The second group was 10 mice injected daily with $10 \mathrm{mg}$ of vitamin $\mathrm{E}$ (dl- $\alpha$-Tocopheryl acetate prepared by EISAI Co., Ltd.) for 20 days. Each animal was killed by decapitation. Bits of testes were dissected out quickly and fixed in buffered isotonic $\mathrm{OsO}_{4}$ solution at $4^{\circ} \mathrm{C}$ for 2 hours. After fixation, the tissues were washed in Ringer's solution, rapidly dehydrated in ethanol series and then embedded in Epon 812 according to Luft's method. The thin sections were cut on a JUM-4 ultramicrotome (Japan Electron Optics Laboratory Co., Ltd.), and then stained in a $0.5 \%$ uranyl acetate alcohol solution for 1 hour. Sections were viewed in HUA 11 electron microscope (Hitachi Ltd. Tokyo Japan).

\section{Observations}

Normal Testicular Interstitial Cells (Fig. 1, 2, 3)

These cells are generally oval or irregularly rectangular in shape. Between adjacent cells many interstices (Fig. 1) are clearly observed. The cell surface exposed to the interstices is sometimes covered with microvilli and in some cases small hollowed cell surface studded with numerous microvilli is recognized at perivascular space (Fig. 3).

The mitochondria are moderate in size, commonly oval or rodshaped and their internal matrices exhibit abundant irregular tubular cristae (Fig. 2).

In cytoplasm, smooth surfaced endoplasmic reticulum (sER) (Fig. 1) is abundant except in perinuclear area in which rough surfaced endoplasmic reticulum ( $\mathrm{rER}$ ) relatively well developed as small sacks or small flattened sacks. Mainly sER is generally recognized as vesicles, however occasionally it appeared as membrane whorls (Fig. 1) or cluster of vesicles which possess sometimes electron dense material in its center.

In area in which sER is abundant, a few number of double walled tubules (Fig. 2) are rarely observed. The outer membranes of this structure are occasionally continuous with neighbouring vesicular sER.

Osmiophilic dense bodies appeared in cytoplasm are divided morphologically into two types. Dense bodies of the first type are generally round in shape and bounded by a thin membrane. The second type of dense bodies shows irregular outline, and commonly appears in some areas of the cytoplasm in which sER is predominant and occasionally they are wrapped in several layers of flattened sacks of sER. 
The Golgi apparatus recognized generally in perinuclear area is poorly developed. In the Golgi region, cytoplasmic inclusions corresponding to secretory granules are not present.

Testicular Interstitial Cells Treated with Vitamin E (Fig. 4, 5, 6, 7,8)

In comparison with normal interstitial cells, they are hypertrophied and mainly oval in shape, and touched closely to adjacent cells.

As compared with normal testicular interstitial cells, marked development of sER (Fig. 5) is observed within them and it occupies the greater part of cytoplasm and especially $\mathrm{sER}$ observed as a membrane whorl (Fig. 6, 7, 8) or cluster of vesicles is increased in size and number. Between membrane whorls consisted of only membranous component (Fig. 7) and the structures with an electron dense core (Fig. 8), transitional figures are often observed.

The irregular osmiophilic dense bodies (Fig. 6) are slightly increased in size and number and occasionally their profiles contain many vesicles.

Concerning the Golgi apparatus, no differences are recognized between the normal and the treated.

\section{Discussion}

In interstitial cells of normal mice, sER is well developed as $\mathrm{Christense} \mathrm{n} \mathrm{\&} \mathrm{Fawcett} \mathrm{('66)} \mathrm{noted} \mathrm{in} \mathrm{their} \mathrm{work} \mathrm{and} \mathrm{moreo-}$ ver this development of $\mathrm{sER}$ is recognized also in interstitial cells of other species by several authors ( $\mathrm{Chr}$ is te $\mathrm{n}$ se $\mathrm{n} \& \mathrm{~F}$ a w cet t, ' 61 ; Porter \& Bonneville, '64; Christensen, '65). Especially sER observed as membranous whorl, which was first reported by $\mathrm{Carr} \& \mathrm{C}$ arr ('62), is also found in the mouse.

The testicular interstitial cells are considered as the main source of steroid hormones produced in testes as clearly confirmed by histochemical studies (Baillie \& Griffiths, '64; Mae ir, '65). Furthermore by recent biochemical studies (Toren, et al., '64; Shikita, et al., '64; Lynn \& Brown, '58; Horfmann, '62), testosterone is biosynthesized from cholesterol and the enzymes mediating the synthesis of testosterone from pregnenolone is contained in microsomal fraction and further enzymes involved in biosynthesis of cholesterol are present in microsomal fraction too ( $\mathrm{Ying}$, et al., '65), that is, sER of testicular interstitial cells is the principal site of these enzymes. F a w c ett ('65) suggested that membranes of sER may play the role of reservoir of cholesterol. 
In testes of mice treated with vitamin $\mathrm{E}$, interstitial cells are hypertrophied and their sER is markedly developed in comparison with the normal. From studies described above, these changes may mean that the interstitial cells are hyperfunctional in steroid hormone production.

Concerning membrane whorls, they are more abundant in vitamin $\mathrm{E}$ administered mice in comparison with the normal and moreover transitional figures are often observed between the structure consisted of membranous component and that with electron dense material.

These figures may possibly be interpreted as the results of the requirements of much cholesterol and thereafter the releasing of own cholesterol of the sER in hyperfunctional state. These ultrastructural changes of testicular interstitial cells of the mouse administered with vtiamin E, which suggest an increased steroid hormone production, are well consistent with reports of $\mathrm{Yam}$ a da \& Ukei ('57) and I c h i h a r a ('66) that administration of vitamin E activates the function of $\mathrm{LH}$ secretion of mouse anterior pituitary.

\section{Summary}

10 male mice of 14 weeks of age were treated daily with $10 \mathrm{mg}$ vitamin $\mathrm{E}$ injection for 20 days. After the treatment, they were decapitated and their testes were examined by electron microscope.

1) By administration of vitamin E, testicular interstitial cells are enlarged and the sER is markedly developed, especially the membranous whorls are more abundant in comparison with normal interstitial cells.

2) From these data, it is conceivable that vitamin E administration activates the function of steroid hormone production in the testicular interstitial cells.

\section{Acknowledgement}

The author wishes to express his sincere thanks to Prof. Dr. Kazumaro $\mathrm{Ya}$ a a a for his constant support and valuable advices in the course of this work. 


\section{References}

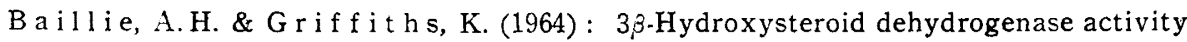
in the mouse Leydig cell. J. Endoc. 29: 9

Carr, I. \& Carr, J. (1962): Membranous whorls in the testicular interstitial cell. Anat. Rec. $144: 143$

Christensen, A.K. \& Fawcett, D.W. (1961): The normal fine structure of opossum testicular interstitial cells. J.B.B.C. $9: 653$

Christensen, A.K. (1965): The fine structure of testicular interstitial cells in guinea pig. J. Cell Biol. $26: 911$

Christènen, A.K. \& F a w c et t, D. W. (1966): The fine structure of testicular interstitial cells in mice. Am. J. Anat. 118:551

Evans, H. M. \& B is hop, K.S. (1922): On the existence of a hitherto unrecognized dietary factor essential for reproduction. Science $56: 650$

Evans, H. M. \& B u r r, G. O. (1927): The antisterility vitamin, fat soluble E. Memoir Univ. of Calif. 8: 1 Cited from Mason (1929)

F a w cet t, D. W. (1965): Structural and functional variations in the membranes of the cytoplasm. In: Intracellular membranous structure. Ed. by S. Seno and E. V. Cow d ry. Japan Society for Cell Biology, Okayama. Pp 15-40.

Fujino, K. \& Yoshioka, I. (1962): Histological observations of the testes of the vitamin $\mathrm{E}$ administered mouse. Okajimas Fol. anat. jap. 38 : 239

Gries b a ch, W. E., et al., (1957): Changes in pituitary gonadotrophs of the vitamin E-deficient male rat. Endoc. 60: 729

Horfmann, F.G. (1962): The inhibition by testis microsomes of corticosterone formation by adrenal mitochondria. Biochim. et Biophys. acta $65: 511$

I c h i h a r a, I. (1966): Unpublished data.

J u hasz-Schaffer, A. (1931): Arbeiten über des E-Vitamin, I Veränderungen der Keimdrüsen während der E-Avitaminose. Virch. Arch. 281: 3

$\mathrm{J} u$ h a s $z$-Sch affer, A. (1932): Arbeiten über des E-Avitaminose. VII Gewebemen-

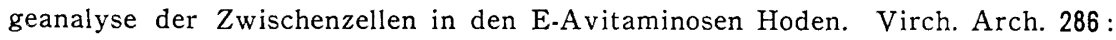
834

Kudrjaschov, B.A. (1930): Das Vitamin E und die Produktion des Testikularhormons. Endok. 7:91

Kudjaschov, B. A. (1931): Vitamin E and the male secondary sex characters. Tranns. Dynam. of Development 6:63 Cited from Mason (1939)

L y n n, W.S., \& B r ow n, R.H. (1958): The conversion of progesterone to androgens by testes. J. Biol. Chem. 232: 1015

Ma eir, D. M. (1965): Species variation in testicular $\Delta^{5}-3 \beta$-hydroxysteroid dehydrogenase activity: absence of activity in primate Leydig cells. Endoc. 76: 463

M a s o n, K.E. (1926): Testicular degeneration in albino rats fed a purified food ration. J. Exp. Zool. $45: 159$

Mas on, K.E. (1939): Relation of the vitamins to the sex gland. Sex and internal secretions, edit. by E. Allen., 2nd Edit., p 1149 Williams and Wilkins, Baltimore.

Marchesi, F. (1935): Indazini spermentali sulla importanza della vitamin E per la funzione reprosuttiva dei ratti alvini. Spermentali 89: 119 Cited from Mason (1939)

Nelson, W.O. (1933): Studies in the anterior hypophysis. III The anterior hypophysis in vitamin E-deficient rat. Anat. Rec. 56:241

Porter, K. R. \& Bonneville, M. A. (1964): An introduction to the fine structure of cells and tissues. IInd Edit. Plate 15. Lea and Fediger, Philadelphia. 
Shik it a, M. \& T a ma oki, B. (1965): Testosterone formation by subcellular particles of rat testes. Endoc. $76: 653$

Tore n, D., et al., (1964): In vitro enzymatic cleavage of the cholesterol side chain in rats testes preparations. Steroids $3: 381$

$\mathrm{V}$ a n W a g e $\mathrm{n}$ en, G. (1925): Histological changes in the male rat hypophysis following degeneration of the germinal epithelium. Anat. Rec. $29: 398$

Y a m a d a, K., \& U k e i, T. (1957): The effect of vitamin $E$ injection on the anterior pituitary of the rat, with special reference to the deita-cell. Kaibo Z. 32: 89 (Japanese abstract)

Y in g, B. D., et al, (1965): Testicular sterols. III Effect of gonadotrophins on the biosynthesis of testicular sterols. Biochim. et Biophys. acta 100:256

\section{Explanation of Figures}

Fig. 1. Low power electron micrograph of a mouse interstitial cell (Isc) lying near seminiferous tubules (sem). In cytoplasm, sER is well developed as small vesicle and membrane whorl (arrow). $\times 3000$

Fig. 2. Higher magnification of left upper part of Fig. 1. A several number of double walled tubules (dwt) are present. At the end of them, outer membranes are continuous with vesicle of sER. Mitochondria (Mt) are seen and their internal matrices exhibit abundant tubular cristae. $\times 10000$

Fig. 3. Higher magnification of an interstitial cell. In middle upper part, the hollowed cell surface (arrow) is studded with numerous microvilli (mv). Mitochondria $(\mathrm{Mt}), \mathrm{sER}$ and free ribosomes are seen. $\times 10000$

Fig. 4. Testicular interstitial cells (Isc) of the mouse treated with vitamin E. These cells are rounded in shape and enlarged in comparison with the normal. The sER is well developed in the greater part of cytoplasm. Membrane whorl $(\mathrm{W})$ is clearly recognized. Irregular dense bodies are increased and scattered throughout the cytoplasm (arrow). $\times 3000$

Fig. 5. Enlargement of Fig. 4. A portion of cytoplasm is filled with vesicle-like sER. Mitochondria in which internal matrices lost its electron density are found. At left upper corner microvilli $(\mathrm{mv})$ are seen. $\times 10000$

Fig. 6. Higher magnification of an interstitial cell. Abundant vesicle-like sER are observed. Irregular dense bodies (arrow) contain vesicles. Two membrane whorls (W) of relatively small size are seen and one of them possess irregular dense body in its central region. $\times 10000$

Fig. 7. This structure exhibits concentric lamellae of tubular sER, however, at its central region it tends to exhibit amorphous material of low electron density. $\times 10000$

Fig. 8. An irregular dense body is surrounded by concentric lamelle of tubular sER. $\times 10000$ 


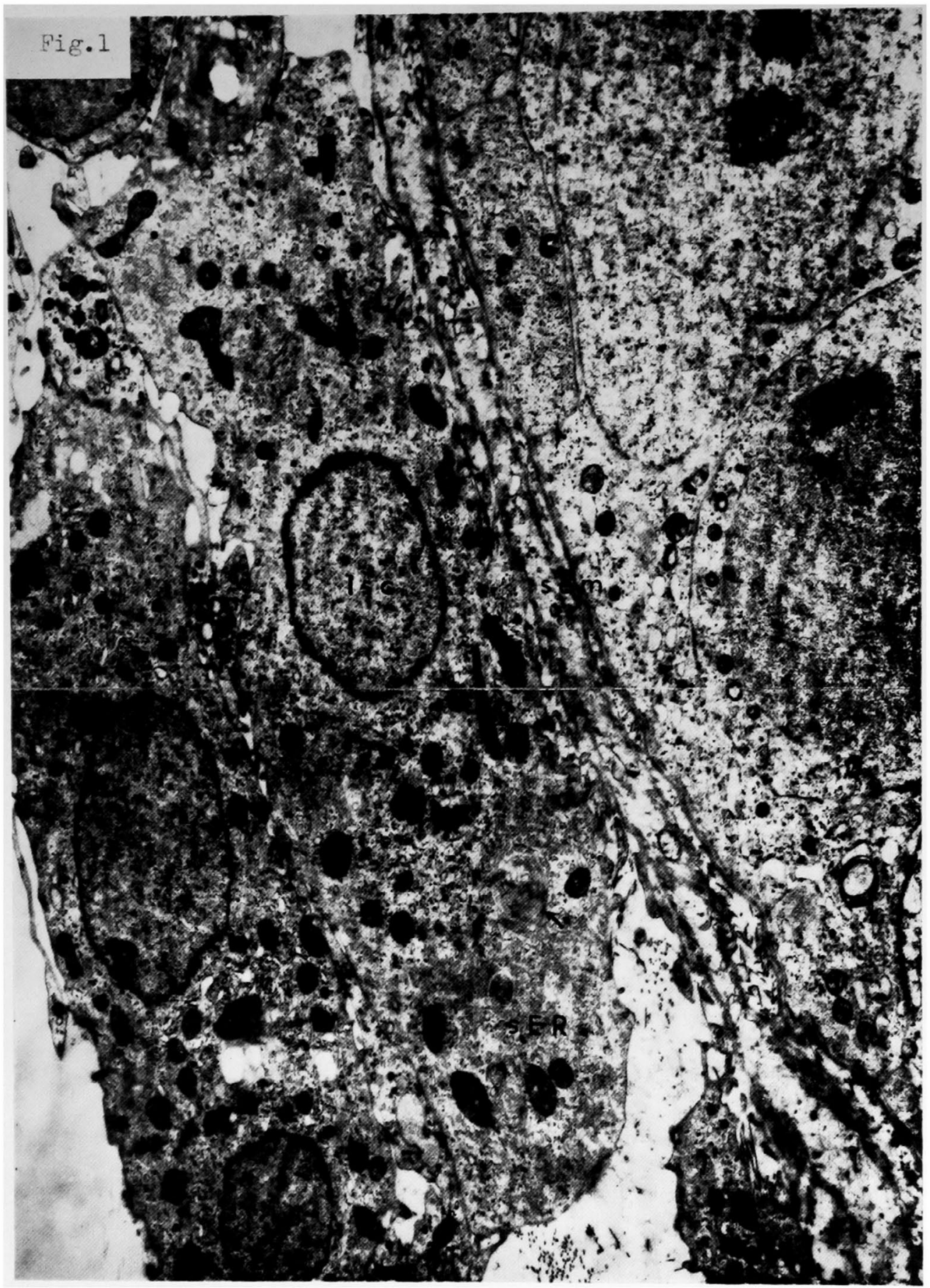


Plate II
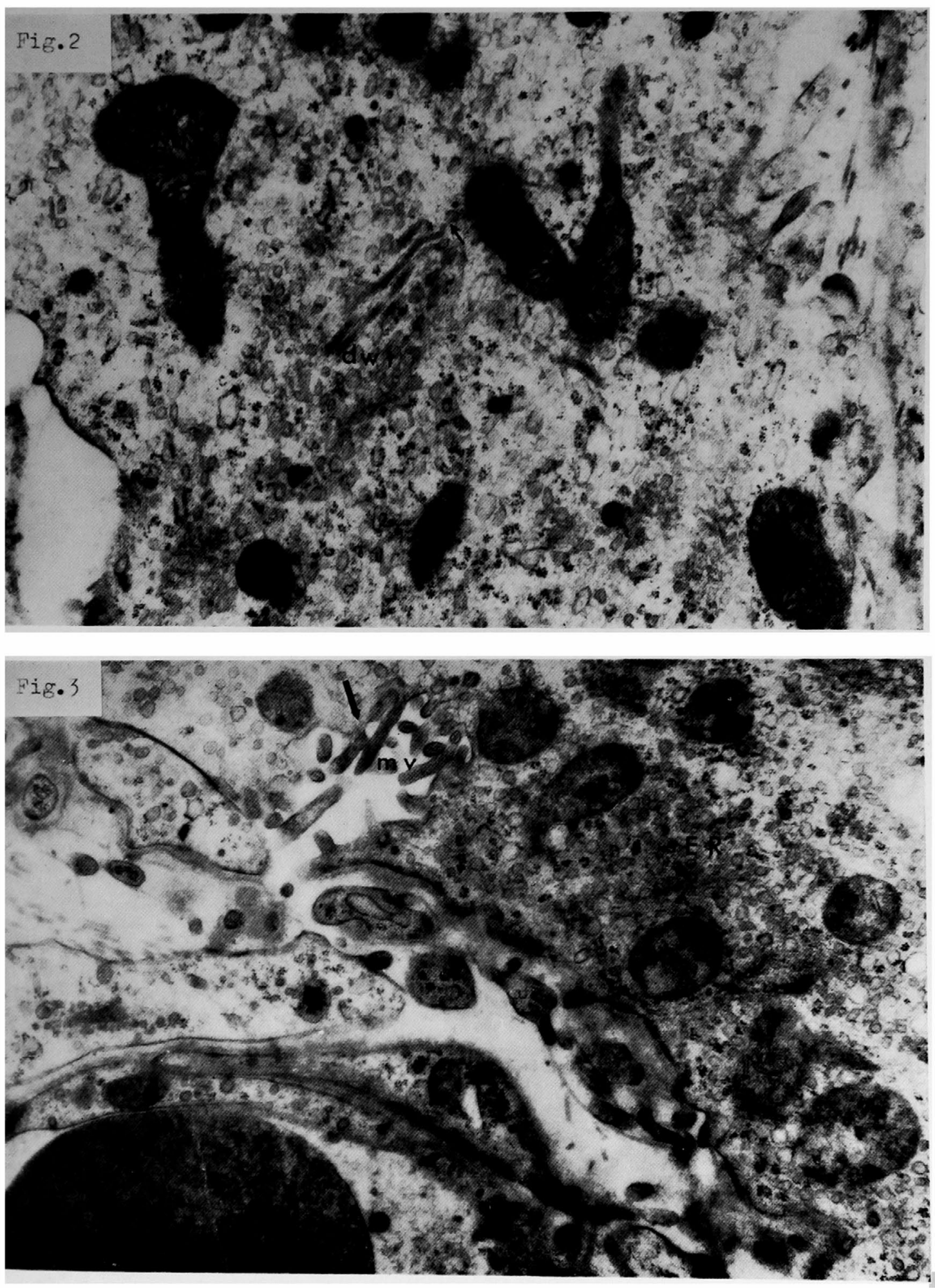

I. Ichihara 


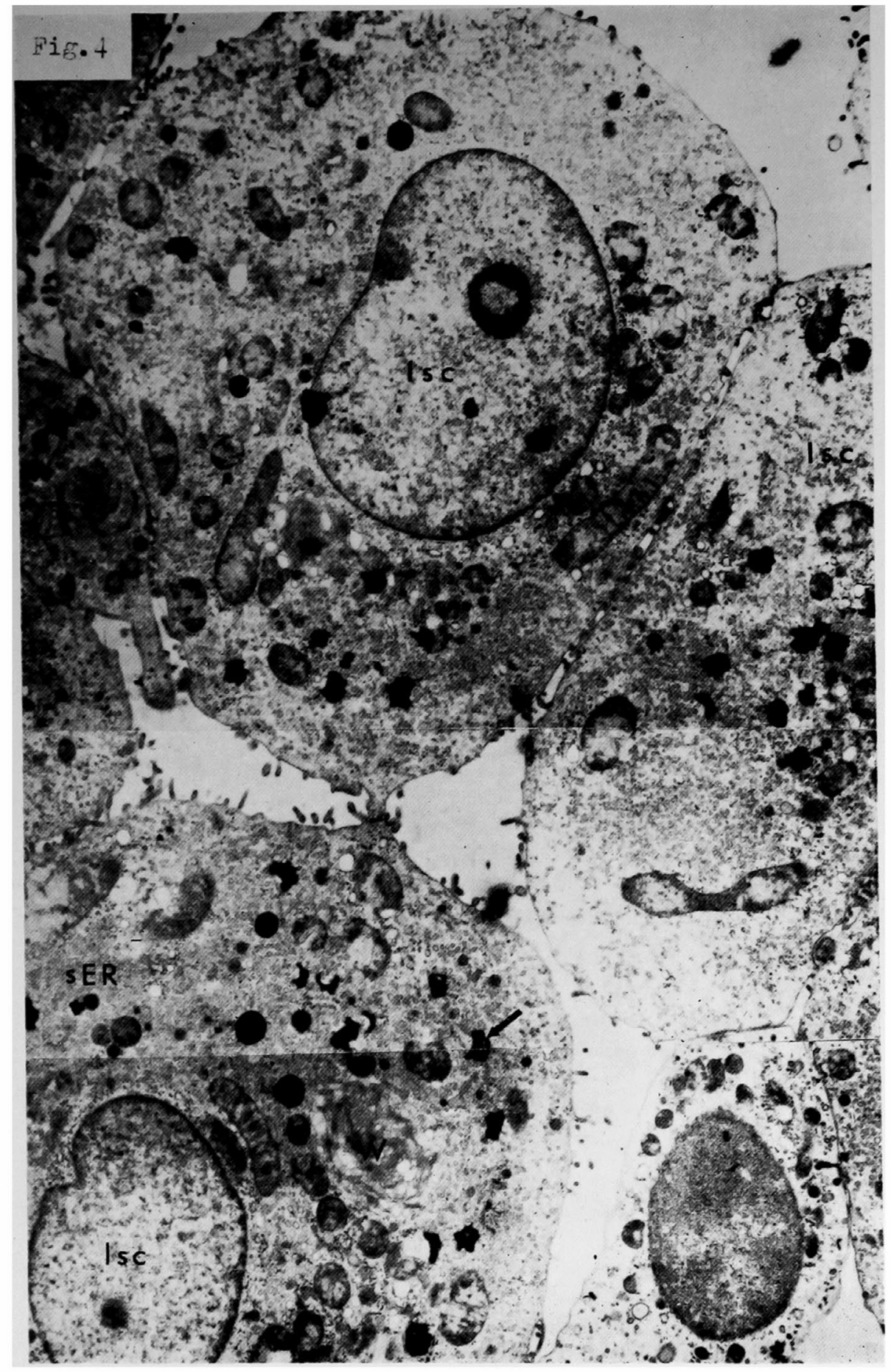



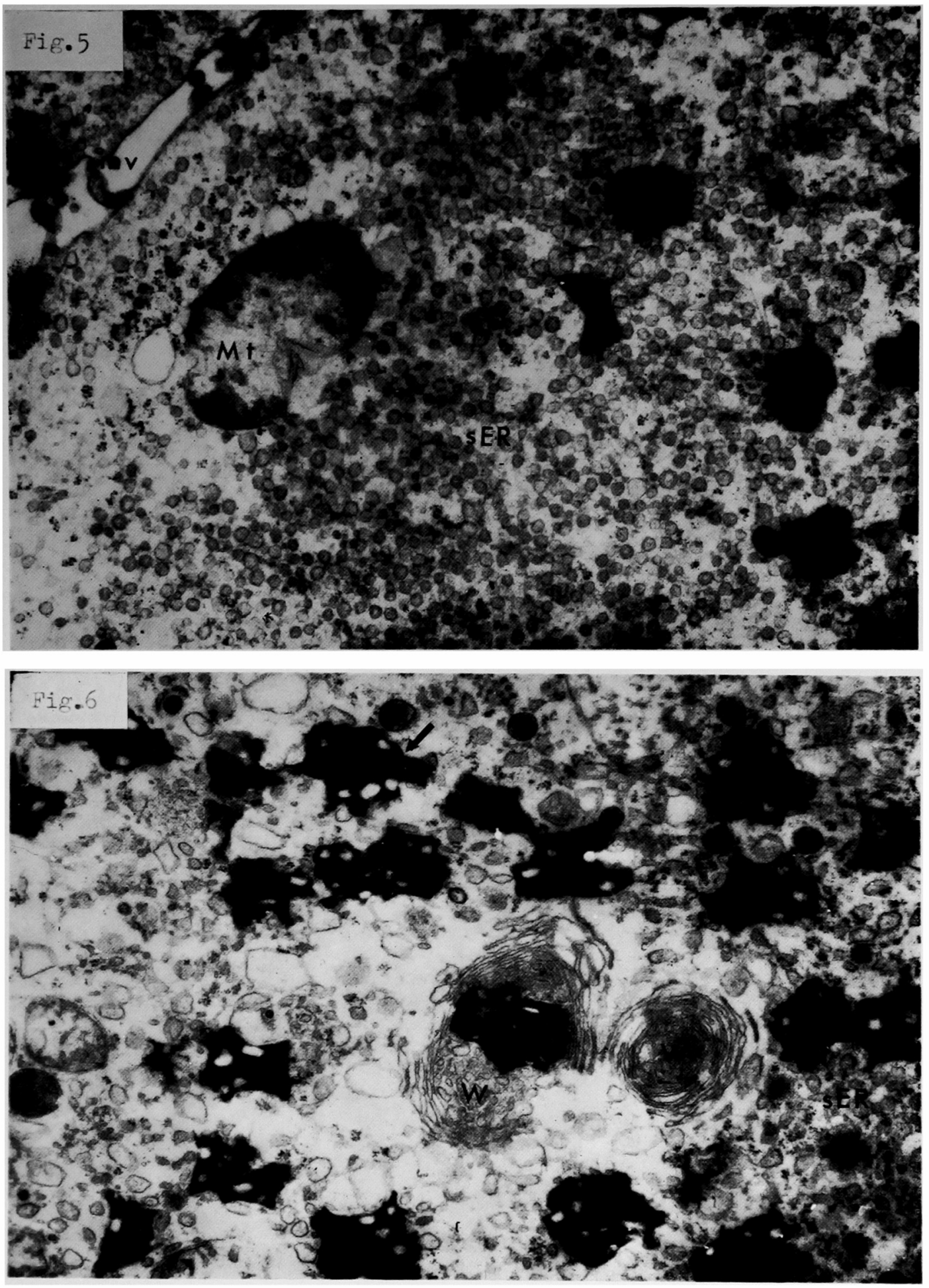

I. Ichihara 
Plate V
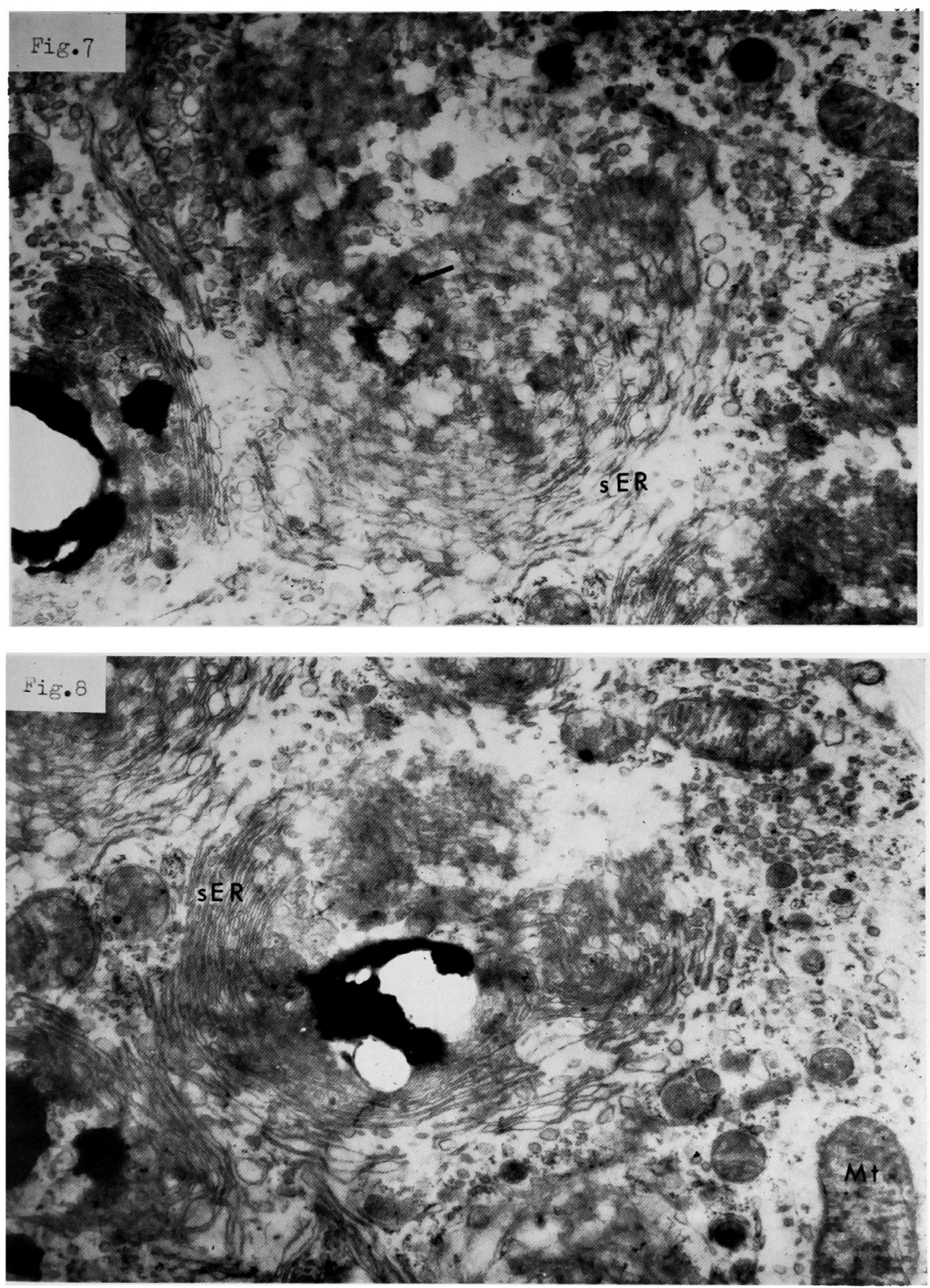

I. Ichihara 